\title{
Estimating the prevalence of milk, egg, and wheat allergies in the Canadian population
}

\author{
Lianne Soller ${ }^{*}$, Joseph Fragapane ${ }^{1}$, Moshe Ben-Shoshan², Daniel Harrington ${ }^{3}$, Reza Alizadehfar², \\ Lawrence Joseph ${ }^{1,4}$, Yvan St Pierre ${ }^{1}$, Samuel Godefroy ${ }^{5}$, Susan Elliott ${ }^{3}$, Ann Clarke ${ }^{1,6}$ \\ From AllerGen NCE Inc.'s Fifth Annual Research Conference: Innovation from Cell to Society \\ Québec City, QC, Canada. 7-9 February 2010
}

\section{Background}

Milk and egg are the most common allergens in childhood. Recent reports also indicate that wheat may contribute to a significant number of food-related anaphylactic events. However, there have so far been no Canadian studies to assess the prevalence of these three important allergens. Our objective was to estimate the prevalence of milk, egg, and wheat allergies in the Canadian population.

\section{Materials and methods}

We performed a cross-sectional, nationwide, telephone survey adapted from a questionnaire used by Sicherer in the US to assess the prevalence of other food allergies $[1,2]$. Telephone numbers were randomly selected from the electronic white pages and an information letter was mailed to households. Respondents were eligible to participate if they were 18 or older, were living in the household, and appeared to have no language-mentalhearing barriers to understanding the questions. To optimize response rates and minimize selection bias, up to ten attempts were made to contact households, calling was done on different days and at different times during the day. Individuals were asked whether they had an allergy to milk, egg, and/or wheat.

\section{Results}

Of 10,596 households surveyed, 3666 responded, representing 9667 individuals (35\% response rate). Of these, $202(2.09 \%$ [95\% CI, 1.81,2.39\%]) self-reported an allergy to milk, $77(0.8 \%[0.63,0.99 \%])$ to egg, and $74(0.77 \%$ $[0.6,0.96 \%])$ to wheat. Egg allergy was more prevalent in children than adults, and wheat allergy was more

\footnotetext{
'Division of Clinical Epidemiology, McGill University Health Centre, Montreal, Canada

Full list of author information is available at the end of the article
}

prevalent in adults than children. Both egg and wheat allergies were more prevalent in households with a postsecondary graduate. Regional differences between allergies to milk, wheat and egg were also evident, with Quebec showing a lower prevalence compared to elsewhere in Canada. The unusually high prevalence of milk and wheat allergy in adults is not consistent with the literature [3,4], and may be due to participant confusion with lactose intolerance and celiac disease, respectively. Currently, our research team is contacting participants from the survey in order to validate their report of allergy to milk, egg and/or wheat.

\section{Conclusions}

This is the first nationwide Canadian study to determine the prevalence of milk, egg, and wheat; three allergens which affect many Canadians and may cause life-threatening anaphylactic reactions. Because of the potential danger associated with having a food allergy, it is crucial to undertake novel research studies to better understand the natural history, diagnosis, and management of food allergy so that we may improve the quality of life of allergic Canadians.

\section{Author details \\ 'Division of Clinical Epidemiology, McGill University Health Centre, Montreal, Canada. ${ }^{2}$ Division of Pediatric Allergy and Clinical Immunology, McGill University Health Centre, Montreal, Canada. ${ }^{3}$ School of Geography and Earth Sciences, McMaster University, Hamilton, Canada. ${ }^{4}$ Department of Epidemiology and Biostatistics, McGill University, Montreal, Canada. ${ }^{5}$ Food Directorate, Health Products and Food Branch, Health Canada, Ottawa, Canada. 'Division of Allergy and Clinical Immunology, McGill University Health Centre, Montreal, Canada.}

\section{Published: 26 November 2010}

\section{References}

1. Sicherer SH, Munoz-Furlong A, Sampson HA: Prevalence of peanut and tree nut allergy in the United States determined by means of a random 
digit dial telephone survey: a 5-year follow-up study. JACI 2003,

112:1203-1207.

2. Sicherer SH, Munoz-Furlong A, Sampson HA: Prevalence of seafood allergy in the United States determined by a random telephone survey. $\mathrm{JACl}$ 2004, 114:159-165.

3. Keet CA, Matsui EC, Dhillon G, Lenehan P, Paterakis M, Wood RA: The natural history of wheat allergy. Ann Allergy Asthma Immunol 2009, 102:410-415.

4. Dias A, Santos A, Pinheiro JA: Persistence of cow's milk allergy beyond two years of age. Allergol Immunopathol (Madr) 2010, 38:8-12.

doi:10.1186/1710-1492-6-S3-P37

Cite this article as: Soller et al:: Estimating the prevalence of milk, egg, and wheat allergies in the Canadian population. Allergy, Asthma \&

Clinical Immunology 2010 6(Suppl 3):P37.

Submit your next manuscript to BioMed Central and take full advantage of:

- Convenient online submission

- Thorough peer review

- No space constraints or color figure charges

- Immediate publication on acceptance

- Inclusion in PubMed, CAS, Scopus and Google Scholar

- Research which is freely available for redistribution

Submit your manuscript at www.biomedcentral.com/submit 